\title{
Lahirnya UUD.1945: \\ Suatu Tinjauan Historis Penyusunan dan Penetapan UUD 1945
}

\section{Saifudin}

UUD 1945 disusun dan ditetapkan dalam suasan revolusi. The founding fathers sangat menyadari bahwa UUD 1945 sebagai UUD Kilat. Proses penyusunan dan penetapan UUD lebih untuk memenuhi syarat formal dalam berdirinya negara. Pembahasan berbagai materi muatan UUD relatif lancar, meskipun kadang dilakukan secara voting. Khusus untuk hubungan negara dan agama yang mengkristal dalam dasarnegara terjadi tarik-menarik yang tajam antara kekuatan nasionalis islami dengan nasionalis sekuler.

$\mathrm{M}$ emasuki tahun 1945 tentara Jepang dalam peperangan di Asia Tenggara mengalami kekalahankekalahan dan semakin terdesak oleh negara-negara Sekutu. Menyadari kondisinya yang tidak menguntungkan, Pemerintah Jepang mulai memperhatikan nasib bangsa indonesia. Berbagai langkah politik ditempuh oleh Pemerintah Jepang untuk menarik simpati dan dukungan bangsa Indonesia dalam melawan tentara Sekutu. Perwujudan secara kongkrit terhadap janjijanjj politik Pemerintah Jepang, adalah dibentuknya Badan Penyelidik Usaha Persiapan Kemerdekaan Indonesia (BPUPKI) pada tanggal 1 Maret 1945.' Pendirian BPUPKI ini mempunyai tujuan untuk menyelidiki hal-hal yang penting mengenai kemerdekaan Indonesia serta menyusun pelbagai rencana yang penting lainnya. ${ }^{2}$ Jadi, tugasnya masih sederhana bagi usaha pembentukan suatu negara merdeka. Artinya badan ini tidak mempunyai kewenangan ke arah terbentuknya Negara Indonesia merdeka secara kongkrit.
Pembentukan badan ini bagi Pemerintah Jepang tampaknya lebih merupakan suatu strategi politik dari pada keinginan secara nyata untuk memberikan kemerdekaan kepada Indonesia. Hal ini mengingat pada tahùn 1943 masalah indonesia telah diputuskan untuk secara berangsur-angsur dimasukkan ke dalam wilayah Kerajaan Jepang. ${ }^{3}$

'Sri Soemantri M,1987. Prosedur dan Sistem Perubahan Konstitusi, Bandung, Cetakan IV, Alumni, hlm. 24 dalam catatan kaki nomor 20. Lihat juga George Mc Turnan Kahin, 1980, Nasionalisme dan Revolusi di indonesia, terjemahan Ismail bin Muhammad dan Zaharom bin Abdul Rashid, Kuala Lumpur, Cetakan Pertama, Dewan Bahasa dan Pustaka Kementerian Pelajaran Malaysia, hlm. 151. Sementara itu A.G. Pringgodigdo mengemukakan bahwa pembentukan BPUPKI adalah tanggal 29 April 1945. Lihat A.G. Pringgodigdo, Perubahan Kabinet Presiensiil Menjadi Kabinet Parlementer, Yayasan Fonds UGM, Yogyakarta, tanpa tahun, hlm. 12.

${ }^{2}$ A.G. Pringgodigdo, loc. cit.

${ }^{3}$ Sri Soemantri M, op. cit., him. 17. 
Pembentukan BPUPKI oleh Pemerintah Jepang ini disertai dengan penunjukan ketuanya yaitu $\mathrm{Dr}$. Radjiman Wediodiningrat dan dibantu oleh dua orang wakil ketua yaitu RP Soeroso dan Ichibangase. Jumlah anggota BPUPKI adalah 62 orang termasuk ketua dan dua orang wakil ketuanya ${ }^{4}$ Pada permulaan persidangan periode kedua, Ketua BPUPKI telah melakukan penambahan jumlah anggota sebanyak enam orang. ${ }^{5}$

Dari keseluruhan keanggotaan BPUPKI - tampak bahwa badan ini belum sepenuhnya merupakan perwakilan dari bangsa Indonesia secara keseluruhan. Sebab, meskipun terdapat anggota-anggota yang berasal dari luar Jawa, tetapi anggotaanggota BPUPKI hanya pemimpinpemimpin Indonesia yang berada di pulau Jawa. ${ }^{6}$ Dilihat dari segi asal kelahirannya, perwakilan terbanyak dari Jawa Tengah yang hampir mencapai 26 orang $(41,93 \%)$ dari total keseluruhan anggota.BPUPKI. Urutan berikutnya adalah perwakilan dari Jawa Timur sebanyak 14 orang $(22,58 \%)$, dan disusul oleh Jawa Barat sebanyak 11 orang (15\%). Selebihnya sebanyak 11 orang (15\%) berasal dari luar Jawa. Akan tetapi ada daerah-daerah seperti Bali dan Nusa Tenggara yang belum terdapat perwakilannya. Meskipun demikian dilihat dari unsur golongan, tampaknya BPUPKI cukup representatif, sebab di dalamnya terdapat keterwakilan dari golongan nasionalis, islam, Katholik, Arab dan Tionghoa. ${ }^{7}$

\section{Penyusunan Rancangan UUD 1945 Oleh BPUPKI}

\section{Persidangan Periode Pertama 29 Mei-1 Juni 1945}

BPUPKI yang dibentuk pada tanggal 1 Maret 1945, pelantikannya baru dilakukan tanggal 28 Mei 1945. Dalam menjalankan tugasnya BPUPKI telah mengadakan sidang-sidangnya yang dapat dibagi dalam dua periode yakni pertama tanggal $29 \mathrm{Mei}$ 1945 s/d 1 Juni 1945 dan kedua tanggal 10 Juli 1945 s/d 17 Juli 1945. Meskipun pada awal pembentukannya, badan ini hanya bertugas untuk melakukan penyelidikan terhadap hal-hal yang penting bagi kemerdekaan, namun kenyataannya badan ini telah melangkah jauh menuju persiapan Indonesia merdeka. Agenda dari sidangsidangnya menunjukkan bahwa BPUPKI telah melangkah sebagai suatu badan yang secara sadar berada pada posisi untuk membentuk negara.

Dalam persidangan periode pertama, BPUPKI telah memulai tugasnya dengan membicarakan masalah yang sangat penting yakni tentang dasar negara. Ada beberapa tokoh yang berpartisipasi dalam menyampaikan pikiran-pikiran dan pandangan-pandangan mengenai dasar negara. Adapun tokoh-tokoh tersebut adalah sebagaimana tabel 1.

4 Moh. Tolchah Mansoer, 1977, Pembahasan Beberapa Aspek Kekuasaankekuasaan Eksekutif dan Legislatif di indonesia, Jakarta, Cetakan kedua, Pradnya Paramita, hlm. 322.

${ }^{5}$ Moh.. Yamin, 1971,Naskah Persiapan UUD 1945, Jilid Pertama, h.lm. 145.

${ }^{6}$ Mohammad Hatta, Sekitar Proklamasi, Cetakan Kedua, Tintamas, Jakarta, 1970, hlm. 19. Lihat pula George Mc Turnan Kahin, op. cit., hlm. 151.

${ }^{7}$ Diolah dari biodata anggota BPUPKI dan PPKI terbitan Sekretariat Negara. Lihat Saafroedin Bahar dk., Risalah Sidang BPUPKI dan PPKI, Cetakan Kedua, Edisi II, Sekretariat Negara , Jakarta, 1992, him. lampiran bagian B. 


\section{Tabel 1. Rapat BPUPKI Periode Pertama 29 Mei - 1 Juni 1945}

\begin{tabular}{|r|c|c|c|c|}
\hline No. & Tanggal & Acara & Tempat & Pembicara \\
\hline 1. & $29-5-45$ & Pembicaraan Dasar Negara & Gedung Pejambon & Moh. Yamin \\
\hline 2. & $31-5-45$ & $\begin{array}{c}\text { Pembicaraan Dasar Negara } \\
\text { (lanjutan) } \\
\text { Pembicaraan Daerah Negara } \\
\text { dan Kebangsaan } \\
\text { Indonesia }\end{array}$ & --idem-- & Soepomo \\
3. & $1-6-45$ & $\begin{array}{c}\text { Pembicaraan Dasar Negara } \\
\text { (lanjutan) }\end{array}$ & --idem-- & Somin \\
\hline
\end{tabular}

Sumber: Diolah dari Risalah Sidang BPUPKI dan PPK ${ }^{\beta}$

Dari data tersebut terlihat hanya tiga tokoh pembicara yakni Moh. Yamin, Soepomo dan Soekarno. Padahal selain tokoh-tokoh tersebut masih ada tokoh pembicara yang lain misalnya Moh. Hatta. ${ }^{9}$ Sementara itu jika dilihat dari segi materi pidato, sidang periode pertama ini tidak saja membahas mengenai dasar negara, tetapi telah disinggung pula tentang daerah dan kebangsaan Indonesia. Adapun pokokpokok pikiran dan pandangan tokoh-tokoh tersebut dapat disajikan dalam rangkuman sbb.:

\section{a. Pidato Mohammad Yamin}

Pidato Mohammad Yamin dalam sidang BPUPKI periode pertama ini dilakukan dua kali. Pidato pertama disampaikan pada tanggal 29 Mei 1945 yang membahas tentang dasar negara, sedangkan pidato kedua disampaikan tanggal 31 Mei 1945 yang membahas tentang daerah dan kebangsaan Indonesia. Pada kesempatan pidato yang pertama Moh. Yamin mengemukakan pikiran dan pandangan tentang lima asas dan dasar negara kebangsaan Republik Indonesia yakni: pertama, peri-kebangsaan; kedua, peri-kemanusiaan; ketiga, peri-ketuhanan; keempat, peri-kerakyatan; dan kelima, kesejahteraan rakyat. Ketika membahas dasar yang keempat, yakni peri-kerakyatan Moh. Yamin mengemukakan adanya enam sifat-sifat yang tidak dapat dipakai dan sembilan sifat-sifat yang harus dijadikan syarat mutlak dalam membentuk faham negara Indonesia.. ${ }^{10}$ Selain menyampaikan tentang pokok-pokok pikiran tentang asas dan dasar negara, Moh. Yamin juga menyampaikan "Rancangan Sementara Perumusan Undang-undang Dasar Republik Indonesia" sebagai lampirannya. ${ }^{11}$

\section{b. Pidato Soepomo}

Berbeda dengan pembicara sebelumnya yang telah menyampaikan lima asas dan dasar dalam membentuk negara, Soepomo pada kesempatan pidatonya mempermasalahkan tentang "Staatsidee" yakni menurut dasar apa negara Indonesia akan didirikan. Bertolak dari pertanyaan tersebut, maka lebih lanjut Soepomo mengemukakan bahwa ada tiga aliran

${ }^{8}$ Saafrudin Bahar dkk., op. cit., hlm. 7 - 72

${ }^{9}$ Sri Soemantri M, op. cit., hlm. 25. 100.

10 Mohammad Yamin, op. cit., hlm. 9911 Ibid., hlm. 106. 
pikiran tentang pendirian negara yakni: pertama, teori individualisme; kedua, teori golongan; ketiga, teori integralistik. Dari tiga alternatif yang ditawarkan tersebut, menurut Soepomo yang paling cocok untuk pendirian negara Indonesia adalah teori integralistik yakni negara yang bersatu dengan seluruh rakyatnya yang mengatasi seluruh golongan-golongannya dalam bidang apapun. ${ }^{12}$

\section{c. Pidato Soekarno}

Menurut Soekarno dasar negara itu menyangkut "philosofische grondslag" yakni fundamen, filsafat, pikiran yang sedalamdalamnya untuk di atasnya didirikan gedung Indonesia merdeka yang kekal dan abadi. ${ }^{13}$ Dengan berdasarkan pada pemahaman dasar negara sebagai suatu "philosofische grondslag" (Weltanschaung) ini Soekarno mengajukan lima dasar negara yakni: pertama, kebangsaan Indonesia; kedua, internasionalisme atau peri-kemanusiaan; ketiga, mufakat atau demokrasi; keempat, kesejahteraan sosial; dan kelima, ketuhanan. ${ }^{14}$ Lima dasar-dasar negara tersebut oleh Soekarno dinamakan "Pancasila"15, maka tanggal 1 Juni 1945 waktu disampaikan dikenal sebagai hari lahirnya Pancasila. Selanjutnya dari lima dasar negara tersebut dapat diperas menjadi tiga yakni: socio-nationalisme, sociodemokratie dan ke-Tuhanan. Akhirnya Soekarno mengemukakan bahwa dari lima dasar dijadikan tiga dan yang tiga dapat dijadikan satu yakni "gotong royong" yang merupakan perkataan asli indonesia. ${ }^{16}$

Selanjutnya dalam mengakhiri sidangsidang BPUPKJ periode pertama, sebanyak 38 orang anggota mengadakan pertemuan dan kemudian membentuk Panitia Kecil yang terdiri dari dua kepanitiaan sebagaimana pada tabel 2 .
Dari tabel tersebut terlihat bahwa terdapat lima orang yang merangkap dalam dua kepanitiaan yakni Soekarno, Moh. Hatta, Moh. Yamin, KH Wachid Hasjim dan Maramis. Selanjutnya untuk Panitia Kecil 8 Anggota ini berhasil menyusun inventarisasi usulan-usulan sebagai berikut:

1. Usulan yang meminta Indonesia merdeka selekas-lekasnya;

2. Usulan yang meminta mengenai dasar negara;

3. Usulan yang meminta mengenai soal unifikasi atau federasi;

4. Usulan yang meminta mengenai bentuk negara dan kepala negara;

5. Usulan yang meminta mengenai warga negara;

6. Usulan yang meminta mengenai daerah;

7. Usulan yang meminta mengenai agama dan negara;

8. Usulan yang meminta mengenai pembelaan; dan

9. Usulan yang meminta mengenai soal keuangan. ${ }^{17}$

Sementara itu Panitia Kecil 9 Anggota yang bertugas menyusun "Pembukaan Hukum Dasar" terbagi dalam dua kelompok besar yaitu pihak nasionalis Islam dan pihak

:2 lbid., hlm. 113. Faham negara integralistik yang diperkenalkan oleh Soepomo ini sampai dengan dasa warsa sembilan puluhan masih menjadi perdebatan yang belum ada penyelesaiannya. Ada yang sependapat dan memberikan alasan untuk menguatkan dukungannya seperti Moerdiono, Padmo Wahyono, A Hamid Attamimi dll. Akan tetapi ada pula yang menolak dengan alasanalasan yang menyangkalnya seperti Ismail Sunny, Marsilam Simanjuntak, Adnan Buyung Nasution dll.
${ }^{13}$ ibid., hlm. 61.
${ }^{14}$ Ibid., hlm. 69-77.
${ }^{15} \mathrm{lbid}$., hlm. 78.
${ }^{16} \mathrm{Ibid}$, hlm. 79 . 
Tabel 2. Panitia-panitia Kecil dalam Rangka Mengakhiri Sidang-sidang BPUPKI Periode Pertama

\begin{tabular}{|c|c|c|c|}
\hline No. & Nama Kepanitiaan & Anggota & Tugas \\
\hline 1. & $\begin{array}{l}\text { Panitia Kecil } \\
8 \text { Orang Anggota }\end{array}$ & $\begin{array}{c}\text { Soekarno (Ketua) } \\
\text { Ki Bagus Hadikusumo } \\
\text { KH Wachid Hasjim } \\
\text { Moh. Yamin } \\
\text { Sutardjo } \\
\text { Maramis } \\
\text { Oto Iskandar Dinata } \\
\text { Moh. Hatta }\end{array}$ & $\begin{array}{l}\text { Menginventarisir } \\
\text { dan menyusun } \\
\text { usul-usul yang } \\
\text { masuk }\end{array}$ \\
\hline 2. & $\begin{array}{c}\text { Panitia Kecil } \\
9 \text { Orang Anggota }\end{array}$ & $\begin{array}{c}\text { Soekarno (Ketua) } \\
\text { Moh. Hatta } \\
\text { Moh. Yamin } \\
\text { Moh. Yamin } \\
\text { Achmad Subardjo } \\
\text { Maramis } \\
\text { KH Abdul Kahar } \\
\text { Moezakkir } \\
\text { KH Wachid Hasjim } \\
\text { Abikoesno } \\
\text { Tjokrosujoso } \\
\text { H Agus Salim }\end{array}$ & $\begin{array}{c}\text { Menyusun } \\
\text { Pembukaan } \\
\text { Hukum Dasar }\end{array}$ \\
\hline
\end{tabular}

Sumber: Diolah dari Naskah Persiapan Undang-Undang Dasar $1945 .^{18}$

nasionalis sekuler. ${ }^{19}$ Antara dua kelompok tersebut terdapat perbedaan dalam melihat masalah agama dan negara, namun pada akhirnya dicapai kesepakatan yang berhasil dituangkan dalam "Rancangan Pembukaan"20 yang ditandatangani oleh sembilan orang anggota pada tanggal 22 Juni $1945 \mathrm{di}$ Jakarta dan dikenal dengan "Piagam Jakarta"21

Berkenaan dengan Piagam Jakarta ini menarik untuk dikaji lebih lanjut. Pertama. bahwa rumusan sila-sila Pancasila tidak sama persis dengan yang dikemukakan oleh Moh Yamin maupun Soekarno. Rumusan sila pertama telah berpihak bagi keuntungan kepentingan dari nasionalis Islam dengan perumusannya "Ketuhanan dengan kewajiban menjalankan syariat Islam bagi pemeluk-pemeluknya". Padahal dalam Panitia Sembilan terdapat wakil dari golongan Kristiani/Katholik yakni A. A.
Maramis. Kedua, bahwa pemikiran Soepomo tentang teori negara integralistik yang mengutamakan persatuan dan kesatuan di atas semua paham golongan, tampaknya diterima sebagai sila ketiga "Persatuan Indonesia". Akan tetapi dalam masalah hubungan agama dan negara, teori integralistik Soepomo tidak dapat diterima. Sebab, dalam Piagam Jakarta terdapat rumusan "Ketuhanan dengan kewajiban menjalankan syariat Islam bagi pemelukpemeluknya". Ini berarti bahwa negara telah berpihak kepada umat Islam yang merupakan jumlah penduduk terbesar di Indonesia.

17 lbid.

${ }^{18}$ Moh. Yamin, op. cit., hlm. 147-153

${ }^{19}$ Endang Saifudin Anshari, op. cit., hlm. 26.

${ }^{20}$ Moh. Yamin, op. cit., hlm. 154. 
Lahirnya UUD 1945: Suatu Tinjauan Historis Penyusunan dan..., Saifudin

Tabel 3. Rapat Besar BPUPKI 10 Juli 1945

\begin{tabular}{|c|c|c|}
\hline No. & Acara & Keterangan \\
\hline 1. & $\begin{array}{l}\text { Laporan Hasil } \\
\text { Panitia Kecil }\end{array}$ & $\begin{array}{c}\text { Disampaikan oleh Soekarno selaku Ketua Panitia Kecil : } \\
\text { a. Ada } 9 \text { klasifikasi usulan yang masuk } \\
\text { b. Rancangan Pembukaan Hukum Dasar }\end{array}$ \\
\hline 2. & $\begin{array}{l}\text { Pembahasan } \\
\text { Bentuk Negara }\end{array}$ & $\begin{array}{l}\text { Ada sekitar } 10 \text { pembicara yang mempermasalahkan antara } \\
\text { republik atau monarkhi. Akhirnya distem dengan hasil : } \\
\qquad \begin{array}{l}\text { a. Republik } 55 \text { orang. } \\
\text { b. Kerajaan } 6 \text { orang } \\
\text { c. lain-lain } 2 \text { orang. } \\
\text { d. Blangko } 1 \text { orang. }\end{array}\end{array}$ \\
\hline 3. & $\begin{array}{l}\text { Pembahasan } \\
\text { Batas Negara }\end{array}$ & $\begin{array}{c}\text { Penyampaian pandangan umum tentang batas-batas } \\
\text { negara oleh } 3 \text { anggota. }\end{array}$ \\
\hline
\end{tabular}

Sumber: Diolah dari Naskah Persiapan Undang-Undang Dasar $1945 .{ }^{22}$

\section{Persidangan BPUPKI Periode /I 10 Juli-17 Juli 1945}

Setelah sidang-sidang BPUPKI periode pertama $29 \mathrm{Mei}-1$ Juni 1945 selesai dengan berbagai usulan-usulan yang telah diinventarisir dan disepakatinya Piagam Jakarta 22 Juni 1945, badan ini memasuki sidang-sidang BPUPKI periode kedua yang dilaksanakan pada tanggal 10 Juli - 17 Juli 1945. Agenda-agenda persidangan periode kedua ini dapat disajikan sbb.:

\section{a. Rapat Besar 10 Juili 1945}

Dalam rapat besar BPUPKI tanggal 10 Juli 1945 ini, pokok-pokok pembicaraan disajikan dalam tabel 3.

Dalam sidang tanggal 10 Juli 1945 ini masalah yang menarik antara lain diterimanya bentuk republik melalui pemungutan suara. Ini berarti bahwa pada mulanya tidak ada kesepakatan mengenai bentuk negara republik atau monarkhi. Antara bentuk republik dan bentuk monarkhi dilihat dari penetapan kepala negaranya, memang mempunyai konsekuensi yang berbeda. Monarkhi atau kerajaan, kepala negara ditentukan atas dasar keturunan dan masa jabatan yang tidak terbatas. Sedangkan republik, kepala negara dilandasi oleh asas persamaan dan masa jabatannya dibatasi untuk waktu tertentu. Dengan dipilihnya bentuk republik untuk Indonesia, berarti di dalamnya tercermin adanya pembagian kekuasaan rakyat seluruhnya yang merupakan perwujudan cita-cita pergerakan kemerdekaan ${ }^{23}$

\section{b. Rapat Besar BPUPKI Tanggal 11 Juli 1945}

Rapat besar BPUPKI tanggal 11 Juli 1945 ini, pokok-pokok pembicaraannya disajikan tabel 4.

Dalam sidang tanggal 11 Juli 1945 berbagai masalah yang menarik untuk dilihat lebih lanjut seperti pengangkatan Mohammad Yamin oleh Ketua BPUPKI dalam Panitia Keuangan dan Perekonomian yang diketuai oleh Muhammad Hatta. Padahal Muhammad Yamin dalam persidangan telah banyak menyampaikan pikiran dan pandangan

\footnotetext{
${ }^{21}$ Endang Saifuddin Anshari, op. cit., hlm. 27.

22 Ibid., him, 145 -195
} 
Tabel 4. Rapat BPUPKI 11 Juli 1945

\begin{tabular}{|c|c|c|}
\hline No. & Acara & Keterangan \\
\hline 1. & $\begin{array}{l}\text { Pembahasan } \\
\text { Lanjutan } \\
\text { Batas Negara }\end{array}$ & $\begin{array}{l}\text { Ada } 4 \text { pilihan wilayah negara : } \\
\text { a. Hindia Belanda dahulu } \\
\text { b. Hindia Belanda dahulu + Borneo Utara + Papua + } \\
\text { Timor semuanya } \\
\text { c. Hindia Belanda daluulu + Malaka + Borneo Utara + } \\
\text { Papua + Timor dan kepulauan sekelilingnya } \\
\text { d. Hindia Belanda dahulu minus Papua } \\
\text { Dari } 4 \text { alternatif tersebut setelah dikalkulasi hasilnya : } \\
\text { a. Alternatif kedua yaitu (b) } 39 \text { orang } \\
\text { b. Alternatif pertama yaitu (a) } 19 \text { orang } \\
\text { c. Alternatif ketiga yaitu (c) } 6 \text { orang } \\
\text { d. Alternatif lain-lain l orang } \\
\text { e. Alternatif blangko } 1 \text { orang }\end{array}$ \\
\hline 2 . & $\begin{array}{l}\text { Pembahasan } \\
\text { Rancangan } \\
\text { UUD }\end{array}$ & $\begin{array}{l}\text { Pada pembahasan awal rancangan UUD, terdapat sekitar } 8 \\
\text { orang yang berbicara dengan materi sbb. : } \\
\text { a. Perlunya mencantumkan bahwa kemerdekaan kita juga } \\
\text { dengan bantuan Dai Nippon } \\
\text { b. Sifat UUD yang mudah diubah } \\
\text { c. Masalah keturunan Arab dan Tionghoa } \\
\text { d. Sifat kesementaraan UUD karena dibuat tergesa-gesa } \\
\text { e. Sistematika dan materi yang perlu diatur dalam UUD }\end{array}$ \\
\hline 3. & $\begin{array}{l}\text { Pembentukan } \\
\text { Panitia- } \\
\text { panitia }\end{array}$ & $\begin{array}{l}\text { Setelah selesai pembahasan awal bahan Rancangan UUD, } \\
\text { dibentuk panitia-panitia sbb.: } \\
\text { a. Panitia Perancang UUD dengan } 19 \text { orang anggota dan } \\
\text { Soekarno sebagai ketuanya } \\
\text { b. Panitia Pembelaan Tanah Air dengan } 22 \text { anggota dan } \\
\text { Abikusno sebagai ketuanya } \\
\text { c. Panitia Keuangan dan Perekonomian dengan } 22 \\
\text { anggota dan Mohammad Hatta sebagai ketuanya. }\end{array}$ \\
\hline
\end{tabular}

Sumber: Diolah dari Naskah Persiapan Undang-Undang Dasar $1945 .^{24}$

secara sistematis berkaitan dengan materi muatan rancangan undang-undang dasar. ${ }^{25}$ Berbagai anggota memprotes tentang penempatan Muhammad Yamin dalam Panitia Keuangan dan Perekonomian.
23 lbid., hlm, 172.

${ }^{24} \mathrm{Jbid}$. hlm, $199-254$

${ }^{25}$ Adapun berbagai usulan Muhammad Yamin tersebut antara lain tentang susunan pemerintahan, pemerintahan atasan, 
Lahirnya UUD 1945: Suatu Tinjauan Historis Penyusunan dan..., Saifudin

Tabel 5. Rapat Panitia Perancang Undang-Undang Dasar 11 Juli 1945

\begin{tabular}{|c|c|c|}
\hline No. & Acara & Keterangan \\
\hline 1. & $\begin{array}{l}\text { Pembahasan } \\
\text { Materi UUD }\end{array}$ & $\begin{array}{l}\text { a. Membahas masalah unitarisme, federalisme dan } \\
\text { bondstaat. Ada } 8 \text { orang berbicara dan setelah diundi } \\
\text { segenap anggota setuju unitarisme kecuali } 2 \text { orang. } \\
\text { b. Dipersoalkan lagi rumusan "Ketuhanan dengan } \\
\text { kewajiban menjaiankan syariat Islam bagi pemeluk- } \\
\text { pemeiuknya" tetapi tidak berhasil. } \\
\text { c. Membahas masalah jumiah pimpinan negara yakni satu } \\
\text { atau beberapa orang. Akhirnya diterima yang satu } \\
\text { orang dengan } 10 \text { suara dan } 9 \text { orang tidak setuju. } \\
\text { d. Membahas masalah sifat UUD. Ada yang hanya } \\
\text { menginginkan yang bisa dijalankan di masa perang, ada } \\
\text { juga yang menginginkan dimasukkannya hal-hal yang } \\
\text { meskipun belum dapat dijalankan di masa perang. }\end{array}$ \\
\hline 2. & $\begin{array}{l}\text { Pembentukan } \\
\text { Panitia }\end{array}$ & $\begin{array}{l}\text { Membentuk Panitia Kecil Perancang UUD dengan } 7 \\
\text { anggota dan Ketua Soepomo. }\end{array}$ \\
\hline
\end{tabular}

Sumber: Diolah Naskah Persiapan Undang-undang Dasar. ${ }^{29}$

Berbagai upaya telah ditempuh untuk menarik Muhammad Yamin masuk dalam Panitia Perancang Undang-undang Dasar, tetapi. tidak dikabulkan oleh Ketua BPUPKI. ${ }^{26}$ Selain penempatan Muhammad Yamin, masalah yang menarik dalam Rapat 11 Juli 1945 adalah disadarinya oleh Wongsonegoro bahwa pembuatan Undang-undang Dasar dalam suasana yang tergesa-gesa sehingga sifatnya sementara ${ }^{27}$. Bahkan Kolopa-king menghendaki agar Undang-undang Dasar yang dibuatnya mudah diubah dan disesuaikan dengan zaman yang akan datang. ${ }^{28}$

\section{c. Rapat Panitia Perancang Undang- Undang Dasar}

Setelah rapat besar BPUPKI tanggal 11 Juli 1945 selesai dengan dibentuknya berbagai kepanitiaan, maka Panitia Perancang Undang-undang Dasar yang diketuai oleh Soekarno mengadakan rapatrapat sebagai berikut:
(1). Rapat Panitia Perancang Undang- undang Dasar 11 Juli 1945
Dalam rapat Panitia Perancang Undang-undang Dasar tanggal 11 Juli 1945 ini, pokok-pokok pembicaraannya adalah sebagaimana tabel 5.

tengahan dan bawahan, perlindungan hakhak rakyat, adanya enam kekuasaan di Indonesia yang terdiri dari (1) presiden dan wakil presiden; (2) Majelis Permusyawaratan Rakyat; (3) Dewan Perwakilan; (4) Majelis Pertimbangan; (5) Balai Agung dan Mahkamah Tinggi; dan (6) kementerian. Ibid., hilm $226-241$
${ }^{26}$ lbid., hlm 257
${ }^{27}$ Ibid., hlm, 224
${ }^{28}$ ibid., hlm, 217
${ }^{29} \mathrm{Ibid}$. hlm, $257-260$ 
Masalah yang menarik dalam Rapat Panitia Perancang Undang-undang Dasar 11 Juli 1945, adalah dipersoalkannya kembali "Ketuhanan dengan kewajiban menjalankan syariat Islam bagi pemelukpemeluknya", tetapi tidak berhasil. ini menunjukkan bahwa hasil kompromis antara nasionalis Islami dengan nasionalis sekuler yang tertuang dalam Piagam Jakarta 22 Juni 1945 benar-benar merupakan jalan terbaik bagi bangsa Indonesia dalam membentuk Indonesia merdeka. Dengan demikian katakata "Ketuhanan dengan kewajiban menjalankan syariat Islam bagi pemelukpemeluknya" telah teruji untuk yang kedua kalinya dalam persidangan BPUPKI. Dan yang mempersoalkan sama-sama dari kalangan Kristiani/Katholik namun dari orang yang berbeda.

Selanjutnya dalam menanggapi sifat Undang-undang Dasar, disadari bahwa pembuatan Undang-undang Dasar berada dalam suasana perang. Meskipun demikian terdapat dua pendapat dalam melihat sifat Undang-undang Dasar. Pendapat pertama mengemukakan bahwa yang dimasukkan dalam Undang-undang Dasar adalah hal-hal yang dapat dijalankan dalam suasana perang. ${ }^{31}$ Jadi pendapat pertama sangat sederhana dan pragmatis. Akan tetapi pendapat kedura menginginkan bahwa tidak hanya hal-hal yang dapat dijalankan dalam masa perang, tetapi juga hal-hal yang walaupun belum dapat dilaksanakan sebaiknya dimasukkan pula dalam Undangundang Dasar. ${ }^{32}$ Jadi pendapat kedua ini agak lebih ideal apabila dibandingkan dengan pendapat pertama.

\section{(2). Rapat Panitia Perancang Undang- undang Dasar 13 Juli 1945}

Dalam rapat Panitia perancangan Undang-undang Dasar tanggal 13 Juli 1945 ini, pokok-pokok pembicaraannya adalah sebagaimana tabel 6 .

Dalam rapat ini persoalan yang menarik antara lain, Wachid Hasjim mengusulkan bahwa pasal 4 ayat (2) presiden harus beragama Islam dan dalam pasal 29 ditegaskan Islam dijadikan agama negara. Usulan ini dilihat oleh Wongsonegoro sebagaj mementahkan kembali hasil kompromis dalam preambul dan Djajadiningrat, nampaknya mengemuka-kan jalan tengah yaitu bahwa dalam praktek sudah tentu yang menjadi presiden orang Indonesia yang beragama Islam..$^{33}$

Selain masalah tersebut, pada kesempatan ini Soepomo selaku Ketua Panitia Kecil Perancang Undang-undang Dasar telah mengemukakan keinginannya akan adanya "Penjelasan" Undang-undang Dasar. Hal itu dikemukakan oleh Soepomo ketika menanggapi anggota Wurjoningrat sebagai berikut:

"Tentang keanggotaan ke Asean sudah dimasukkan dalam pernyataan kemerdekaan dan Preambule, tidak perlu dimasukkan dalam Undangundang Dasar; tetapi hal-hal itu bisa dalam Penjelasan. ${ }^{\text {34 }}$

Dari keterangan Soepomo tersebut terlihat bahwa adanya Penjelasan Undangundang Dasar sudah disadari sejak pembahasan Rancangan Undang-undang Dasar, meskipun bukan merupakan keputusan Rapat Panitia Perancang Undang—undang Dasar BPUPKI tanggal 13 Julj 1945. 
Tabel 6. Rapat Panitia Perancang Undang-undang Dasar 13 Juli 1945

\begin{tabular}{|c|c|c|}
\hline No. & Acara & Keterangan \\
\hline 1. & $\begin{array}{l}\text { Penyampaian } \\
\text { Rancangan } \\
\text { UUD }\end{array}$ & $\begin{array}{l}\text { Rancangan UUD ini terdiri } 15 \text { bab dengan } 42 \text { pasal oleh } \\
\text { Soepomo selaku ketua yang pokok-pokoknya : } \\
\text { a. Kedaulatan dilakukan oleh Badan Permusyawaratan } \\
\text { Rakyat. } \\
\text { b. Untuk sehari-hari presidenlah yang merupakan } \\
\text { penjelmaan kedaulatan rakyat. } \\
\text { c. Presiden dibantu oleh wakil presiden, menteri dan } \\
\text { Dewan Pertimbangan Agung } \\
\text { d. Dalam pembuatan undang-undang presiden harus } \\
\text { semufakat Dewan Perwakilan Rakyat. } \\
\text { e. hak-hak dasar tidak perlu dimasukkan dalam UUD. }\end{array}$ \\
\hline 2. & $\begin{array}{l}\text { Pembahasan } \\
\text { Rancangan } \\
\text { UUD }\end{array}$ & $\begin{array}{l}\text { Ada } 11 \text { orang menanggapi Rancangan UUD yang pokok- } \\
\text { pokoknya antara lain: } \\
\text { a. perdebatan di sekitar presiden harus Islam atau tidak. } \\
\text { b. Masalah hak-hak dasar masuk atau tidak dalam UUD } \\
\text { c. Penegasan masalah "Uni" dengan konsekuensi hanya } \\
\text { Pemerintah Pusat yang boleh berhubungan dengan } \\
\text { negara lain. } \\
\text { d. Perlunya pencatuman keanggotaan Indonesia dalam } \\
\text { negara-negara Asia Timur. }\end{array}$ \\
\hline 3. & $\begin{array}{l}\text { Pembentukan } \\
\text { Panitia } \\
\text { Penghalus } \\
\text { Bahasa }\end{array}$ & $\begin{array}{l}\text { Panitia ini beranggotakan tiga orang yaitu Djajadiningrat, } \\
\text { Agus Salim dan Soepomo. }\end{array}$ \\
\hline
\end{tabular}

Sumber: Diolah dari Naskah Persiapan Undang-undang Dasar. ${ }^{35}$

Masalah lain yang patut memperoleh perhatian adalah penegasan Soepomo ketika menanggapi Latuharhary yang mempertanyakan Pasal 21 dan Pasal 22 Rancangan Undang-undang Dasar yang menurutnya tidak menjamin kedaulatan rakyat. Menanggapi hal ini Soepomo menegaskan yang merupakan penjelmaan kedaulatan rakyat ialah presiden, bukan Dewan Perwakilan Rakyat. ${ }^{36}$
(3). Rapat Besar BPUPKI 14 Juli 1945 Rapat besar BPUPKI 14 Juli 1945 membahas tentang "Pernyataan Indonesia Merdeka" atau Declaration of Independence yang merupakan bagian dari persiapan membentuk Indonesia merdeka, tetapi berada di luar Undang-undang Dasar. Dan sebagaimana diketahui bahwa pada

\footnotetext{
${ }^{35}$ Ibid., hlm, 260 - 270

${ }^{36}$ Ibid., hlm, 297.
} 
akhirnya Proklamasi Kemerdekaan 17 Agustus 1945 dikumandangkan di luar rencana yang telah dijanjikan oleh Pemerintah Jepang. Oleh karena itu bagian rapat besar BPUPKI 14 Juli 1945 ini tidak dibahas oleh penulis, mengingat kurang relevansinya dengan materi penulisan tesis.

\section{(4). Rapat Besar BPUPKI 15 Juli 1945}

Dalam rapat besar BPUPKI tanggal 15 Juli ini, pokok-pokok pembicaraannya dapat disajikan dalam tabel sebagaimana tabel 7 .

Dari rapat besar BPUPKI 15 Juli 1945 yang secara khusus membahas Rancangan Undang-Undang Dasar ini, masalah yang menarik untuk dikaji adalah: pertama masalah hak-hak dasar, kedua masalah pertanggungjawaban menteri, ketiga masalah kekuasaan membanding bagi Mahkamah Agung dan keempat masalah agama Islam sebagai syarat presiden.

Mengenai masalah yang pertama yakni tentang hak-hak dasar, Soekarno dan Soepomo sama-sama berpendapat bahwa adanya hak-hak dasar yang merupakan perwujudan faham individualisme dan liberalisme, tidak perlu ada dalam Undangundang Dasar.

Dalam hal ini Soekarno menegaskan sebagai berikut:

"Maka oleh karena itu, jikalau kita betul-betul hendak mendasarkan negara kita kepada faham kekeluargaan, faham tolong-menolong, faham gotong-royong dan keadilan sosial, enyahkanlah (cetak miring penulis) tiaptiap pikiran, tiap-tiap faham individualisme dan liberalisme dari padanya. ${ }^{.37}$

Sedangkan Soepomo dengan menggunakan pendekatan sistem, mengemukakan sebagai berikut:

"Maka dalam dokumen seperti dokumen yang sangat penting, yang sangat pokok, dokumen negara Undangundang Dasar itu sudah tentu kita harus melaraskan segala pasal-pasal itu dengan sistem itu, artinya tidak bisa kita memasukkan dalam Undangundang Dasar beberapa pasal-pasal tentang bentuk menurut aliran-aliran yang bertentangan. ${ }^{\text {rgg }}$

Sementara itu Muhammad Hatta, dan Muhammad Yamin sama-sama memperjuangkan untuk dimasukkannya hak-hak dasar dalam Undang-undang Dasar. Muhammad Hatta menegaskan sebagai berikut:

"Kita mendirikan negara baru di atas dasar gotong royong dan hasil usaha bersama. Tetapi suatu hal yang saya kuatirkan (cetak miring penulis), kalau tidak ada satu keyakinan atau satu pertanggungan kepada rakyat dalam Undang-undang Dasaryang mengenai hak untuk mengeluarkan suara, yaitu bahwa nanti di atas Undang-undang Dasar yang kita susun sekarang ini mungkin terjadi suatu bentukan negara yang tidak kita setujui. ${ }^{\text {'39 }}$

Sedangkan Muhammad Yamin setelah memberikan contoh-contoh konstitusi yang memuat perlindungan aturan dasar, mengemukakan bahwa aturan dasar tidaklah berhubungan dengan liberalisme, melainkan semata-mata suatu keharusan perlindungan kemerdekaan yang harus diakui dalam undang-undang dasar. ${ }^{40}$

Untuk masa yang kedua tentang pertanggungjawaban menteri, Muhammad Hatta dengan mengambil perbandingan pada Amerika Serikat mengemukakan
${ }^{37}$ Ibid., hlm, 302
${ }^{38}$ Ibid., hlm, 299.
${ }^{39}$ Ibid., him, 330.
40 Ibid., hlm, 360 . 
Lahirnya UUD 1945: Suatu Tinjauan Historis Penyusunan dan..., Saifudin

Tabel 7. Rapat Besar BPUPKI 15 Juli 1945

\begin{tabular}{|c|c|c|}
\hline No. & Acara & Keterangan \\
\hline 1. & $\begin{array}{l}\text { Pidato Pengantar } \\
\text { Rancangan U U D }\end{array}$ & $\begin{array}{l}\text { Pidalo Pengantar Atas Rancangan UUD Disampaikan Oleh Soekamo } \\
\text { Selaku Ketua Panitia Perancang Uud Yang Mencakup Tentang Dasar, } \\
\text { Falsafah dan Sistem UUD. . Pokok-Pokok Pengantar Soekamo Antara } \\
\text { Lain: } \\
\text { Ada } 11 \text { Orang Menanggapi Rancangan UUD yang Pokok-Pokoknya } \\
\text { Antara Lain : } \\
\text { a. UUD Berdasarkan Kekeluargaan atau Gotong Royong. } \\
\text { b. Faham Liberal-Individualisme Menjadi Sumber Malapetaka- } \\
\text { Malapetaka di dunia. } \\
\text { c. Faham Liberal-Individualisme Jangan Dimasukkan Dalam UUD. } \\
\text { d. Rancangan UUD dengan Kedaulatan Rakyat bukan Kedaulatan } \\
\text { individu. }\end{array}$ \\
\hline 2. & Tanggapan Moh. Hatta & $\begin{array}{l}\text { Keberatan Atas Adanya Pertanggungan Kepada Rakyat Dalam UUD, } \\
\text { Apalagi Negara-Negara Baru Dan Khawatir Akan Menjadi Negara } \\
\text { Kekuasaan. Oleh Karena Itu Perlu Ada Pasal Yang Mengenai Warga } \\
\text { Negara. }\end{array}$ \\
\hline 3. & Uraian dari Soepomo & $\begin{array}{l}\text { Soepomo Selaku Panitia Kecil Perancang UUD Memberikan Uraian Yang } \\
\text { Pada Pokoknya Antara Lain : . } \\
\text { A. Uraian Secara Umum : } \\
\text { 1. Istilah "Hukum Dasar" Berbeda Dengan Istilah "Undang-Undang } \\
\text { Dasar". } \\
\text { 2. Uud Tidak Dapat 'Dimengerti Dengan Hanya Membaca Teksnya } \\
\text { Saja. } \\
\text { 3. Penerimaan Dan Anjuran Aliran Pikiran Kekeluargaan Membawa } \\
\text { Konsekuensi Bahwa UUD Kita Tidak Bisa Lain Mengandung Sistim } \\
\text { Kekeluargaan. Artinya Kita Tidak Bisa Memasukkan Dalam UUD } \\
\text { Beberapa Pasal-Pasal Tentäng bentuk Menurut Aliran-Aliran Yang } \\
\text { Bertentangan. } \\
\text { 4. Adanya Pokok-Pokok Pikiran Yang Terkandung Dalam Pembukaan. } \\
\text { Pokok-Pokok Pikiran Ini Memberi Suasana Batin Kepada UUD. } \\
\text { 5. Pokok-Pokok Pikira Merupakan Cita-Cita Hukum (Rechtsidee) Yang } \\
\text { Menguasai hukum Dasar Baik Tertulis Maupun Dasar Yang Tidak } \\
\text { Tertulis. } \\
\text { 6. Telah Cukup Jika UUD Hanya Memuat Aturan-Aturan Pokok Dari } \\
\text { 7. Pada Pokok Urusan Negara. } \\
\text { Yang Penting Dalam Pemerintahan Adalah. Semangat Para } \\
\text { Penyelenggara Negar. . }\end{array}$ \\
\hline
\end{tabular}




\begin{tabular}{|c|c|c|}
\hline No. & Acara & Keterangan \\
\hline & & $\begin{array}{l}\text { B. Uraian Secara Terperinci : } \\
\text { Dalam Menguraikan Secara Terperinci Rancangan UUD, Soepomo } \\
\text { Membahas Materi-Materi UUD Dengan Pokok-Pokoknya Sbb: } \\
\text { 1. Tentang Bentuk Negara. } \\
\text { 2. Tentang Kedaulatan Rakyat dan Majelis Permusyawaratan Rakyat. } \\
\text { 3. Tentang Susunan, Tugas dan Sidang Majelis Permusyawaratan } \\
\text { Rakyat. } \\
\text { 4. Tentang Presiden dan Pembantu-Pembantunya Yakni Wakil } \\
\text { Presiden, Dewan Pertimbangan Agungdan Menteri-Menteri. } \\
\text { 5. Tentang Pemerintah Daerah. } \\
\text { 6. Tentang Dewan Perwakilan Rakyat. } \\
\text { 7. Tentang Pembuatan Undang-Undang. } \\
\text { 8. Tentang Kekuasaan Kehakiman. } \\
\text { 9. Tentang Keuangan. } \\
\text { 10. Tentang Badan Pemeriksa Keuangan. } \\
\text { 11. Tentang Warga Negara. } \\
\text { 12. Tentang Sistem Pemerintahan. } \\
\text { 13. Tentang Batas Negara. } \\
\text { 14. Tentang Grondrechten. } \\
\text { 15. Tentang Kebudayaan. } \\
\text { 16. Tentang Perekonomian. } \\
\text { 17. Tentang Bahasa Negara. } \\
\text { 18. Tentang Aturan Peralihan. } \\
\text { 19. Tentang Aluran Tambahan. }\end{array}$ \\
\hline 4. & $\begin{array}{l}\text { Tanggapan dari } \\
\text { anggota lainnya. }\end{array}$ & $\begin{array}{l}\text { Dalam Menanggapi Pengantar dan Uraian Rancangan UUD, ada } 23 \\
\text { orang yang berbicara dan permasalahannyadapat dikelompokkan antara } \\
\text { lain: } \\
\text { 1. masalah pemilihan dan susunan MPR. } \\
\text { 2. masalah hak-hak dasar. } \\
\text { 3. masalah fakir miskin dan anak terlantar. } \\
\text { 4. masalah sistimatika UUD. } \\
\text { 5. masalah wilayah negara. } \\
\text { 6. masalah kekuasaan membanding Balai Agung. } \\
\text { 7. masalah pertangungjawaban menteri. } \\
\text { 8. masalah kedaulatan rakyat. } \\
\text { 9. masalah ibukota negara. } \\
\text { 10. masalah warga-negara. } \\
\text { 11. masalah agama dan syarat sebagai Presiden. }\end{array}$ \\
\hline
\end{tabular}

Sumber: Diolah dari Naskah persiapan Undang-Undang Dasar $1945^{41}$

bahwa tidak adanya pertanggungjawaban menteri di Amerika Serikat karena dianutnya ajaran pemisahan kekuasaan. Sedangkan dalam Rancangan Undang-undang Dasar kita tidak ada pemisahan kekuasaan, oleh karena itu perlu diadakan sistim bertanggungjawab. ${ }^{42}$ Muhammad Yamin meskipun

${ }^{41} \mathrm{lbid}$. hlm, 285-388

42 Ibid., halaman 360 . 
berpendapat bahwa demokrasi parlementer seperti di dunia Barat ditolak, tetapi memperkenalkan sistim tanggung jawab menteri melalui publik opinion seperti yang berlaku di Nippon. Jadi tanggung jawab dan perasaan umum adalah kelahiran kedaulatan rakyat, yang kita junjung tinggi. ${ }^{43}$

Bertalian dengan pendapat tersebut, Soepomo menegaskan bahwa menteri dalam sistem kita hanya pembantu belaka yang kedudukannya tergantung dari presiden. Menteri-menteri hanya tunduk kepada kepala negara. Meskipun demikian menteri adalah pembantu yang harus dihargai, yang mesti dihargai, yang suaranya didengar oleh presiden. Dan apabila menterimenteri tidak disukai oleh Dewan Perwakilan Rakyat, Soepomo mengemukakan sebagai berikut:

"Akan tetapi jika umpamanya terjadi bahwa menteri tidak disukai oleh Dewan Perwakilan Rakyat, meskipun tidak ada votum atau mosi tidak percaya, ahli negara yang bijaksana tentu harus mengerti sikap mana harus dijalankan. Dan kalau perlu tentu menteri sendiri minta akan meletakkan jabatannya, harus mempunyai perasaan tanggung jawab, perasaan harga bagi diri sendiri dan mempunyai political feeling tentang hal itu". ${ }^{44}$

Dari keterangan tersebut, tampak bahwa Soepomo dalam masalah pertanggungjawaban menteri ini bersikap mendua. Artinya di satu sisi dengan tegas menolak parlementarisme, namun di sisi yang lain membenarkan adanya tuntutan moral kepada menteri yang berbuat salah untuk mengundurkan diri.

Sedangkan masalah yang ketiga adalah kekuasaan Balai Agung. Dalam masalah ini Muhammad Yamin mengemukakan bahwa Balai Agung janganlah hanya melaksanakan kekuasaan kehakiman, tetapi hendaknya juga menjadi badan pembanding terhadap undang-undang, apakah bertentangan atau tidak dengan undang-undang dasar. ${ }^{45}$ Akan tetapi pendapat Muhammad Yamin ini ditolak oleh Soepomo yang menegaskan bahwa kekuasaan Mahkamah Agung untuk menguji Undang-undang terhadap Undang-undang Dasar adalah merupakan konsekuensi teori Trias Politika. Padahal Rancangan Undangundang Dasar kita memang tidak memakai sistem yang membedakan prinsipil 3 badan, artinya tidaklah bahwa kekuasaan kehakiman akan mengontrol kekuasaan membentuk undang-undang. ${ }^{46}$

Adapun masalah keempat yang menarik untuk dibahas adalah agama Islam sebagai syarat seorang Presiden. Masalah ini muncul dalam persidangan BPUPKI. karena selalu menjadi perdebatan antara golongan Islam dengan golongan kebangsaan. Meskipun telah diterimanya Piagam Jakarta yang merupakan Rancangan Pembukaan Undang-undang Dasar, tetapi dalam penerapannya ke dalam perumusan pasal-pasal yang menyangkut kepentingan kedua golongan tersebut, ternyata sangat sulit untuk mempertemukan kesatuan pendapat. Pihak golongan Islam yang diwakili antara lain Kahar Muzakkir, $\mathrm{K}$ Masjkur, Hadikusumo, Sanusi dan Pratalykrama berpendapat bahwa presiden harus beragama Islam. Dalam menanggapi keinginan dari golongan Islam tersebut, Soepomo yang termasuk mewakili golongan kebangsaan mengingatkan kembali akan kompromis yang telah dicapai dalam 
Piagam Jakarta yang di dalamnya mengandung makna saling menerima dan memberi antara golongan Islam dan golongan kebangsaan. Lebih lanjut Soepomo mengemukakan sebagai berikut:

"Kita harus percaya, harus memegang teguh apa yang sudah kita janjikan, dan lagi $95 \%$ dari orang Indonesia beragama islam $95 \%$ itu sudah jaminan yang besar yang dalam lapangan apapun tentu akan memberi pengaruh yang sebesar-besarnya (cetak miring penulis). Saya sendiri percaya, sepenuh-penuhnya kepada kekuatan yang begitu besar. Tetapi di luar itu juga sudah ada Perjanjian Charter ${ }^{\text {"47 }}$

Sementara itu Soekarno yang termasuk juga golongan nasionalis menegaskan sebagai berikut:

"Kalau tuan Haji Masjkur menanyakan kepada diri saya sebagai persoon Soekarno, saya seyakin-yakinnya bahwa Presiden Indonesia tentu orang Islam (cetak miring penulis). Tak lain dan tak bukan ialah oleh karena saya melihat dan mengetahui bahwa sebagian besar daripada penduduk Indonesia ialah beragama Islam, bahkan dalam pidato saya di dalam sidang pertama, saya telah menganjurkan sebagai orang Islam, menganjurkan kepada ummat Islam Indonesia, supaya bekerja keras untuk mempropagandakan agama Islam sehebat-hebatnya dalam kalangan rakyat Indonesia, sehingga jikalau betul sebagian besar dari rakyat Indonesia itu jiwanya berkobar dengan api Islam, rohnya menyala-nyala dengan roh Islam, tidak boleh tidak, bukan saja Presiden Republik Indonesia nanti orang Islam, bahkan - saya berkata tiap-tiap undang-undang yang ke luar daripada badan perwakilan bercorak Islam pula (cetak miring penulis)"48
Dengan melihat pada uraian Soepomo dan Soekarno tersebut, sebenarnya secara material dapat menerima syarat agama Islam bagi seorang presiden, akan tetapi keberatan dan menolak jika dirumuskan secara formal dalam Rancangan Undangundang Dasar. Perdebatan ini sedemikian seru sehingga Kahar Muzakkir sampai kepada suatu sikap sebagai berikut:

"Saya tidak ada lagi, kecuali mengusulkan usul saya, yaitu supaya segala berkenaan dengan nama Allah, nama agama dan rakhmat-Nya dan lainlain, pendeknya segala dengan perkataan Allah, rakhmat-Nya, dicoret daripada Undang-undang (Dasar) itu. ${ }^{\text {"49 }}$

Usulan Kahar Muzakkir tersebut didukung oleh Hadikusumo yang mengemukakan sebagai berikut:

"Jadi saya menyetujui usul tuan Abdul Kahar Muzakkir tadi: kalau idiologi islam tidak diterima, tidak diterima. Jadi nyata negara ini tidak berdiri di atas agama Islam dan negara akan netral. Itu terang-terangan saja, (cetak miring penulis)' jangan diambil sedikit kompromis seperti Tuan Soekarno katakan."50

(5). Rapat Besar BPUPKI 16 Juli 1945

Dalam rapat besar BPUPKI tanggal 16 Juli 1945 ini, pokok-pokok pembicaraannya disajikan dalam tabel 8.

Dalam rapat besar BPUPKI 16 Juli 1945 yang merupakan sidang terakhir BPUPKI, agenda yang dibahas adalah melanjutkan pembahasan Rancangan

\footnotetext{
47 lbid., hlm, 378

${ }^{48}$ Ibid, him, 380.

${ }^{49}$ Ibid., hlm, 386.

so Ibid.,
} 
Lahirnya UUD 1945: Suatu Tinjauan Historis Penyusunan dan..., Saifudin

Tabel 8. Rapat Besar BPUPKI 16 Juli 1945

\begin{tabular}{|c|c|c|}
\hline No. & Acara & Keterangan \\
\hline 1. & $\begin{array}{c}\text { Pengantar Soekarno } \\
\text { Panitia Perancangan } \\
\text { UUD }\end{array}$ & $\begin{array}{l}\text { Permohonan Soekarno selaku ketua Panitia Perancang UUD } \\
\text { kepada golongan non Islam untuk menerima usulan rumusan } \\
\text { Panitia yang berkaitan dengan masalah agama dan negara, } \\
\text { yaitu: } \\
\text { 1. Presiden Republik Indonesia haruslah orang Indonesia asli } \\
\text { yang beragama Islam. } \\
\text { 2. Negara berdasar atas ke-Tuhanan dengan kewajiban } \\
\text { menjalankan syariat Islam bagi pemeluk-pemeluknya. } \\
\text { 3. Negara menjarnin kemerdakaan tiap-tiap penduduk untuk } \\
\text { memeluk agamanya dan kepercayaanya masing-masing. }\end{array}$ \\
\hline 2. & $\begin{array}{l}\text { Uraian Soepomo } \\
\text { Ketua Panitia Kecil } \\
\text { Perancang UUD }\end{array}$ & $\begin{array}{l}\text { Selaku Ketua Panitia Kecil Perancang UUD Soepomo } \\
\text { menyampaikan uraian yang pokok-pokoknya adalah sebagai } \\
\text { berikut: } \\
\text { 1. Perubahan sistematika bab-bab UUD dan penempatan } \\
\text { pasal-pasal seiring dengan perubahan urutan bab-babnya. } \\
\text { 2. Diterimanya rumusan "Kemerdekaan untuk berserikatdan } \\
\text { berkumpul, unfuk mengeluarkan pikiran dengan lisan dan } \\
\text { sebagainya ditetapkan dengan undang-undang". } \\
\text { 3. Perkataan "undang-undang" dalam Rancangan UUD dipakai } \\
\text { dengan istilah hukum, artinya peraturan yang dibuat kepala } \\
\text { negara dengan DPR., } \\
\text { 4. Perubahan aturan peralihan dan aturan tambahan yang } \\
\text { menyangkut penomeran. }\end{array}$ \\
\hline 3. & Tanggapan Anggota & $\begin{array}{l}\text { Rancangan UUD setelah melalui beberapa perubahan dan } \\
\text { penyempurnaan, diterima secara bulat oleh anggota. }\end{array}$ \\
\hline
\end{tabular}

Sumber: Diolah dari Naskah Persiapan Undang-Undang Dasar 1945. ${ }^{5 t}$

Undang-undang Dasar. Persidangan ini merupakan kemenangan dari golongan Islam untuk yang kesekian kalinya yakni diterimanya syarat bagi presiden harus beragama Islam. Selain itu, persidangan ini lebih merupakan penyempurnaan rumusanrumusan materi Rancangan Undang-undang Dasar. Pada akhirnya Rancangan Undangundang Dasar ini diterima secara bulat oleh anggota BPUPKI menjadi Undang-undang Dasar. ${ }^{52}$

\section{Penetapan Undang-Undang Dasar 1945 Oleh PPKI}

Setelah BPUPKI menjalankan tugastugasnya dan berhasil menetapkan dua hal yang penting bagi pembentukan Indonesia

\footnotetext{
S1 Ibid., hilm, 389-396.

\$2 /bid., hlm, 396.
} 
merdeka, yakni Rancangan Pembukaan Undang-undang Dasar dan Rancangan Undang-undang Dasar, badan ini pada tanggal 7 Agustus 1945 dibubarkan oleh Pemerintah Jepang. ${ }^{53}$ Dan sebagai tindak lanjut yang lebih konkret terhadap janjijanjinya, Pemerintah Jepang melalui Penguasa Tertinggi Balatentara Dai Nippon di Asia Selatan telah menyetujui akan dibentuknya Panitia Persiapan Kemerdekaan Indonesia (PPKI). Oleh karena itu pada tanggal 9 Agustus 1945, Soekarno, Moh. Hatta dan Radjiman Wediodiningrat berangkat ke markasnya di Saigon guna menerima secara langsung pembentukan PPKI. ${ }^{54}$ Delegasi Indonesia tiba di Saigon tanggal 10 Agustus dan tanggal 12 Agustus 1945 diterima oleh Marsekal Hisaichi Terauchi di Dallat. ${ }^{55}$ Pada kesempatan tersebut Marsekal menjelaskan bahwa tanggal kemerdekaan akan ditentukan oleh Tokio, dan untuk itu di Jakarta harus dibentuk PPKI. ${ }^{56}$ Tugas panitia ini adalah melaksanakan kemerdekaan Indonesia yang daerahnya meliputi daerah Hindia Belanda dahulu. ${ }^{57}$ Panitia ini beranggotakan 21 orang termasuk Soekarno dan Moh. Hatta yang masing-masing adalah selaku ketua dan wakil ketua. Delegasi Indonesia sampai di tanah air tanggal 14 Agustus 1945 dan tanggal 15 Agustus Jepang telah menyerah kalah dengan sekutu. Dengan demikian Jepang sudah tentu tidak dapat lagi untuk menghadiahkan kemerdekaan kepada Indonesia yang semula dijanjikan akan dilaksanakan pada tanggal 24 Agustus $1945 .{ }^{58}$ Tanah-tanah jajahan Jepang termasuk Indonesia berada pada status quo sampai dengan negara-negara sekutu mengambil alih kekuasaannya..$^{59}$

Kekalahan Jepang tersebut segera diketahui oleh tokoh-tokoh perjuangan kemerdekaan baik dari kalangan pemuda maupun yang tua. Oleh karena itu kesempatan inj dimanfaatkan dengan sebaik-baiknya untuk mempersiapkan kemerdekaan Indonesia. Setelah melalui perdebatan strategi perjuangan kemerdekaan, selang dua hari dari Jepang menyerah, tepatnya tanggal 17 Agustus 1945 Proklamasi Kemerdekaan Indonesia dikumandangkan oleh Soekarno dan Mohammad Hatta atas nama bangsa Indonesia di Jalan Pegangsaan Timur 56 Jakarta. Dan ketika itu Indonesia belum mempunyal Undang-undang Dasar yang akan digunakan sebagai landasan konstitusional dalam bernegara. Lembaga-lembaga pemerintahan belum terbentuk. Satu-satunya lembaga yang mewakilj bangsa Indonesia adalah PPKI yang pembentukannya dilakukan oleh Jepang:

Sehari setelah Proklamasi Kemerdekaan Indonesia yakni tanggal 18 Agustus 1945, PPKI mengadakan rapat guna membahas berbagai persoalan dalam rangka melengkapi lahirnya Indonesia merdeka. Sebelum rapat dilaksanakan, Ketua PPKI Soekarno atas tanggungjawabnya sendiri menambah enam orang anggota sehingga jumlah keseluruhan menjadi 27 orang. Penambahan inj dilakukan untuk mengantisipasi suatu pendapat bahwa PPKI merupakan badan bentukan Jepang yang tidak dapat menyanggupi apa-apa lagi untuk pengakuan Indonesia sebagai negara yang merdeka

${ }^{53}$ A. M. W. Pranarka, 1985, Sejarah Pemikiran Tentang Pancasila, Jakarta, Cetakan Pertama, CSIS, hlm, 51.

${ }^{54}$ J.C.T. Simorangkir, op. cit, hlm, 16.

${ }^{55}$ Mohammad Hatta, op. cit., hlm, 20

${ }^{56}$ Sri Somentri M, Prosedur ..., op. cit., $h \mid m, 33$.

57 Mohammad Hatta, op. cit., h/m, 18.

${ }^{58}$ A.G. Pringgodigdo, op. cit., hlm, 15.

${ }^{59}$ Mohammad Hatta, op. cit., hlm, 54-55. 
dan berdaulat. Dengan adanya penambahan anggota ini, Mohammad Hatta mengemukakan bahwa PPKI pada hakekatnya juga Komite Nasional mempunyai sifat yang representatif _sifat perwakilan_ bagi seluruh rakyat Indonesia. ${ }^{60}$ Memang PPKI lebih representatif apabila dibandingkan dengan BPUPKI. Sebab keanggotaan BPUPKI meskipun ada yang dari luar Jawa, tetapi merupakan tokoh-tokoh yang tinggal di Jawa. Sedangkan keanggotaan PPKl, terdapat beberapa anggota yang sengaja didatangkan dari luar Jawa seperti Sumatera, Kalimantan dan Bali. ${ }^{61}$

Adapun agenda persidangan PPKI pada tanggal 18 Agustus 1945 secara ringkas dapat disajikan dalam tabel 8 .

Dalam persidangan PPKL tanggal 18 Agusus 1945, ada beberapa hal yang menarik untuk dikaji lebih lanjut. Pertama, dicoretnya kata-kata "dengan kewajiban menjalankan syariat Islam bagi pemelukpemeluknya", dan dihapusnya syarat presiden harus beragama Islam. Pencoretan kata-kata tersebut merupakan suatu kekalahan bagi golongan nasionalis Islam, telapi merupakan puncak kemenangan bagi perjuangan nasionalis sekuler yang selama persidangan BPUPKI selalu mengalami kekalahan dari golongan nasionalis Islam. Kedua, pernyataan Soekarno selaku Ketua PPKl yang mengemukakan bahwa Undangundang dasar ini adalah Undang-undang Dasar "kilat," Undang-Undang Dasar Sementara yang merupakan revolutiegrondwet. ${ }^{62}$ Dari pernyataan Soekarno tersebut memperlihatkan bahwa pembuatan Undang-undang Dasar berada dalam suasana revolusi yang menuntut adanya tindakan cepat guna kelengkapan kemerdekaan. Ini berarti bahwa PPKI lebih mengutamakan syarat formal adanya suatu Undang-undang Dasar dari pada syarat material yang menyangkut isi dari Undang- undang Dasar. Ketiga, rancangan Undangundang Dasar hasil karya BPUPK1 memberikan manfaat yang besar dalam proses pembahasan dan penetapan Undang-undang Dasar. Meskipun ada usulan-usulan perbaikan redaksi dan sistimatikanya, akan tetapi dapat dikatakan sekitar $75 \%$ naskah rancangan Undangundang Dasar BPUPKI diterima oleh PPKI. Keempat, Mohammad Yamin sebagai orang yang banyak usulan-usulan tentang materi Undang-undang Dasar pada sidang-sidang BPUPKI, ternyata tidak masuk sebagai anggota PPKI. Kelima, Soepomo selaku Ketua Panitia Kecil Perancang Undangundang Dasar pada masa BPUPKI dengan tidak mengurangi rasa hormat dan sumbangan pemikiran anggota yang lainnya - merupakan arsitek dalam pembuatan Undang-undang Dasar.

Demikianlah proses pengesahan dan penetapan Pembukaan Undang-undang Dasar dan Undang-undang Dasar Negara Republik Indonesia pada tanggal 18 Agustus 1945. Yang perlu dicatat adalah bahwa PPKI pada sidang tersebut tidak mengesahkan dan menetapkan adanya Penjelasan Undang-Undang Dasar 1945 sebagaimana yang dapat dilihat dalam Naskah UndangUndang Dasar 1945 selama ini.

\section{Penutup}

Dari pemaparan di atas, nampaklah proses penyusunan dan penetapan UUD 1945 yang penyusunannya dilakukan oleh BPUPKI dilakukan dalam dua kali masa persidangan yaitu tanggal $29 \mathrm{Mei}-1$ Juni 1945 untuk periode pertama dan tanggal 10 Juli - 17 Juli 1945 untuk masa persidangan periode kedua. Sedangkan untuk

\footnotetext{
${ }^{60}$ A.G. Pringgodigdo, 10c. Cit.

61 ibid., halaman 14.

62 Jbid., halaman 410 .
} 
.penetapannya dilakukan oleh PPKI pada tanggal 18 Agustus 1945. Dalam perjalanan penyusunan maupun penetapan UUD 1945 tersebut tampak sekali terjadinya tarikmenarik antara kekuatan nasionalis Islam dengan kekuatan nasionalis Sekuler ketika mengkaji mengenai dasar negara. Selain itu BPUPKI yang berperan dalam penyusunan materi UUD 1945, dapat dilihat dalam tiga aspek yaitu: pertama, aspek keterwakilan wilayah yaitu dari 62 anggota BPUPKI ternyata 41, $93 \%$ dari Jawa Tengah; 22, 58 $\%$ dari Jawa Timur; $15 \%$ dari Jawa Barat; dan $11 \%$ dari luar Jawa. Kedua, aspek kterwakilan golongan yaitu bahwa dalam BPUPKI terdapat golongan nasionalis, Islam, Katholik, Arab dan Tionghoa. Ketiga aspek tugas dan kegiatannya yaitu bahwa BPUPKI berhasil menyusun Rancangan UUD sehingga dapat dikatakan semacam badan konstituante.

Tabel 9. Rapat PPKI 18 Agustus 1945

\begin{tabular}{|c|c|c|}
\hline No. & Acara & Keterangan \\
\hline 1. & $\begin{array}{l}\text { Pengantar Ketua } \\
\text { PPKI }\end{array}$ & $\begin{array}{l}\text { Permohonan agar Rancangan UUD hasil BPUPKI sedapat mungkin } \\
\text { diikuti. Perubahan yang penting-peting saja. Pekerjaan yang kecil-kecil } \\
\text { hendaknya dikesampingkan, agar hari ini pula telah selesai pekerjaan } \\
\text { menyusun UUD dan memilih presiden. }\end{array}$ \\
\hline 2. & $\begin{array}{l}\text { Penjelasan Wakil } \\
\text { Ketua PPKI }\end{array}$ & $\begin{array}{l}\text { a. Penghilangan pernyataan Indonesia Merdeka serta pembukaan yang } \\
\text { lama, dan menggantinya dengan penbukaan hasil Panitia Kecil. } \\
\text { b. Adanya perubahan yang maha penting dalam menyatukan bangsa } \\
\text { yakni : } \\
\text { 1). Pasal } 6 \text { ayat (1) tentang syarat Islam bagi presiden dicoret. } \\
\text { 2). Sebagai konswekuensi dari prembule, maka kata-kata "dengan } \\
\text { kewajiban" dan sebagainya dalam Pasal } 29 \text { ayat (1) dicoret. } \\
\text { c. Perubahan-perubahan pokok lainnya adalah seperti : } \\
\text { 1). Pasal } 4 \text { ayat (1) ditambah dengan "menurut Undang-undang } \\
\text { 2). Pasar" } \\
\text { 3ajal } 4 \text { ayat (2) bahwa wakil presiden jangan 2, tetapi seorang } \\
\text { 3). Pasal } 23 \text { ayat (3) ditambalı satu kalimat Hasil pemeriksaan itu } \\
\text { diberitahukan kepada Dewan Perwakilan Rakyat. }\end{array}$ \\
\hline 3. & $\begin{array}{l}\text { Pengesahan } \\
\text { Pembukaan }\end{array}$ & $\begin{array}{l}\text { Setelah dilakukan perbaikan dan penyempurnaan, maka disahkanlah } \\
\text { Pembukaan Undang-undang Dasar Negara Indonesia. }\end{array}$ \\
\hline 4. & $\begin{array}{l}\text { Penjelasan } \\
\text { Soepomo }\end{array}$ & $\begin{array}{l}\text { Soepomo selaku Ketua Panitia Kecil Perancang UUD menyampaikan } \\
\text { penjelasan berbagai masalah tentang susunan negara dalam UUD antara } \\
\text { lain : } \\
\text { a. Kedaulatan, rakyat dan MPR. } \\
\text { b. Kedudukan presiden. } \\
\text { c. DPR dan pembuatan undang-undang. } \\
\text { d. Pemmbantu-pembantu presiden. } \\
\text { e. DPA } \\
\text { f. Tanggung jawab menteri negara. } \\
\text { g. Susunan pemerintah daerah. }\end{array}$ \\
\hline
\end{tabular}


Lahirnya UUD 1945: Suatu Tinjauan Historis Penyusunan dan..., Saifudin

\begin{tabular}{|c|c|c|}
\hline No. & Acara & Keterangan \\
\hline 5. & Pembahasan UUD & $\begin{array}{l}\text { Ada sekitar } 10 \text { orang pembicara yang materi pembicaraannya dapat } \\
\text { dirangkum sbb: } \\
\text { a. Masalah dekoncentrasi yang sebesar-besarnya. } \\
\text { b. Masalah penyusunan anggaran belanja jika ditolak oleh Badan } \\
\text { Perwakilan Rakyat. } \\
\text { c. Masalah perubahan UUD. } \\
\text { d. Masalah ketua MPR dan DPR. } \\
\text { e. Masalah materi UUD yang cukup memuat pokok-pokoknya } \\
\text { f. Maja. } \\
\text { g. Masalah aturan peralihan. }\end{array}$ \\
\hline 6. & Pengesahan UUD & $\begin{array}{l}\text { Setelah melalui penambahan dan perdaikan, maka disahkan dan } \\
\text { ditetapkan UUD Negara lndonesia. }\end{array}$ \\
\hline
\end{tabular}

Sumber: Diolah dari M.Yamin, 1971, Naskah Persiapan Undang-Undang Dasar 1945, Jilid Pertama. ${ }^{63}$

\section{Daftar Pustaka}

Sri Soemantri M,1987, Prosedur dan Sistem Perubahan Konstitusi, Cetakan IV, Bandung: Alumni.

George Mc Turnan Kahin, 1980, Nasionalisme dan Revolusi di Indonesia, terjemahan Ismail bin Muhammad dan Zaharom bin Abdul Rashid, Cetakan Pertama, Kuala Lumpur: Dewan Bahasa dan Pustaka Kementerian Pelajaran Malaysia.

A.G. Pringgodigdo, tt, Perubahan Kabinet Presidensiil Menjadi Kabinet Parlementer, Yogyakarta: Yayasan Fonds UGM.

Mohammad Tolchah Mansoer, 1977, Pembahasan Beberapa Aspek Kekuasaankekuasaan Eksekutif dan Legislatif di Indonesia,Cetakan kedua, Jakarta: Pradnya Paramita.

Mohammad Yamin, 1971, Naskah Persiapan UUD 1945, Jilid Pertama, $399-437$.

${ }^{63}$ Mohammad Yamin, op. cit., halaman

Jakarta.

Mohammad Hatta, 1970, Sekitar Proklamasi, Cetakan Kedua, Jakarta: Tintamas.

Saafroedin Bahar dkk., 1992, Risalah Sidang BPUPKI dan PPKI, Cetakan Kedua, Edisi II, Jakarta: Sekretariat Negara.

Endang Saifudin Anshari, 1981, Piagam Jakarta 22 Juni 1945 dan Sejarah Konsensus nasional Antara Nasionalis Islami dan Nasionalis Sekuler Tentang Dasar Negara Rl, Cetakan Pertama, Bandung: Perpustakaan Salman ITB.

Marsilam Simanjuntak, 1994, Pandangan Negara Integralistik, Cetakan Pertama, Jakarta: Grafiti.

A.M. W . Pranarka, 1985, Sejarah Pemikiran Tentang Pancasila, Cetakan Pertama, Jakarta: CSIS. 